\title{
THE RESPONDS OF DIRECTIVE SPEECH ACTS BY THE CHARACTERS IN JACK THE GIANT SLYER (2013) MOUIE
}

\author{
Ruminda \\ adnimur@gmail.com, \\ English Study Program, Adab and Humanity Faculty, UIN Sunan Gunung Djati Bandung \\ Neng Nurhamidah S. \\ hamidahsay@yahoo.com \\ Postgraduate Program, UIN Sunan Gunung Djati Bandung
}

\begin{abstract}
This research presents the responds of the hearers as the effects of directive speech acts that are given by the characters in Jack the Giant Slyer (2013) movie. The research is aimed to analyze the categories of responds resulted from the addresses when they are asked to do something by using the theory about directive speech act by Leech (1983). The result of the analysis shows that the responds of the characters that are found in some categories are in the form of action responds, verbal responds, action and verbal responds and no responds. The most type of directive speech acts that is responded by the action is commanding, and the least of it is suggesting.
\end{abstract}

Key Words: responds, effects, directive, speech act

\section{INTRODUCTION}

In a communication, people should pay attention not only to what they say but also to the actions they make. It will help to make the communication more understandable. In attempting to express themselves, people do not only produce utterance containing grammatical structures and words, they perform actions via those utterances (Yule 1996: 47). In pragmatics terms, it is called as speech acts. It is an utterance that contains the actions as the functional unity in communication with considering some aspects of speech situation (Chaer and Agustin 2010: 50)

Leech divided speech acts into some kinds. From those kinds, directive speech acts are mostly found in human life as they are used in daily conversations. Leech (1983: 106) states that directive utterances are intended to produce some action by the hearer. It means that directive speech acts should produce the responds which are appeared in the form of action asked by the speaker. The respond here refers to the notion of an action, though and belief which are caused by illocutionary act. Austin called them as perlocutionary act whereby in the action resulted from uttering sentence (1955: 101).

Seeing that daily life is represented in a movie, thus, many directive speech acts can be found in the conversations between the characters in the movie. Hence, responds of directive speech acts will be analyzed in the Jack the Giant Slyer movie as the object of the research. Itis an American heroic fantasy adventure movie based on the British fairy tales "Jack the Giant Killer" and "Jack the Beanstalk". The movie is directed by Bryan Singer from a screen play by Darren Lemke and Christopher McQuarrie and starring Nicholas Hoult, Eleanor Tomlinson, Ewan McGregor and Stanley Tucci. This movie is premiered on March 01, 2013 in USA.

\section{Speech Act}

One of the studies in pragmatics is speech acts, as pragmatics talks about the utterance of the speaker related to the context. Speech act is one of the core issues of modern pragmatics (Ad-Darraji, 2012: 1). According to Chaer and Agustina (2010: 50), speech acts is an utterance that contains the actions as a functional unity in communication by considering some aspects 
of speech situation. George Yule argues that speech act is the action expressed through the utterance. Each speech act that is expressed by a speaker has certain meaning. Based on Searle's theory, speech acts are "the basic or the minimal units of linguistic communication" (1976:16). Austin adds that speech act refers to an utterance and also the total situation in which the utterance is issued (1960:52).

Speech act is the production or issuance of a sentence token under condition and basic or minimal unit linguistic communication involves linguistic acts (Searle, 1969: 16-17). Speech act is an action performs via utterance containing grammatical structures they perform action via those utterances (Yule, 1996: 47). Speech act is when people do something with language. Nastri, Peña and Hancock (2006) said that the function of speech acts is a functional unit of language that informs people to do things with words, which means the speaker performs an acts of saying something in order to participate in a communication.

\section{THEORITICAL REVIEW Speech Acts Classifications}

Based on the Speech Acts Theory, the illocutionary becomes the central study of the speech acts. Searle in Yule (1996) classified Speech Acts into five types:

1. Declarations

Declarations are those kinds of speech acts that change the world via their utterance. Here, the speaker has to have a special institutional rule.

Example: I now pronounce you husband and wife.

It means that declaration presents an utterance acts that change the conditions or status another person by words.

2. Representatives

Representatives are those kinds of speech acts that state what the speaker believes to be the case or not. For example:

a. It was a warm sunny days.

b. The earth is flat.

It means that representative is an assertion that state something based on the confidence supported by state of affair which factually is represented by the speaker as the statement of facts, assertion, conclusion, and description.

\section{Expressive}

Expressives are those kinds of speech acts that state what the speaker feels. They express psychological states and can be the statement of pleasure, pain, like, dislike, joy, or sorrow. For example:

a. I am really sorry.

b. Congratulation!

It means that expressive shows the expression of psychological state about the situation.

\section{Directives}

Directives are kinds of speech acts that the speaker intends to make someone else to do something which makes the world fit words. In other words, the speaker wants the situation. They express what the speakers want. They are commands, orders, requests, suggestions. Example: Give me a cup of coffee. Make it black.

It means that directives are intended to make the hearer produce some action.

\section{Commissives}

Commissives are those kinds of speech acts that speakers use to commit themselves to some future actions. They speak what the speaker intends. They are promises, threats, refusals, pledges, and they can be performed by speaker alone, or by a speaker as a member of group.

Example: I will be back.

\section{Directive Speech Act}

Directive Speech Acts is speech acts which are attempted by the speaker to the hearer to do something (Saeed, 1997: 212). Directive speech acts is a speech act which asks someone to do something directly. They are commanding, ordering, requesting and suggesting. (Yule 1996: 54) Directive is used when the speaker wants the hearer to do things for him or her. Searle (in Levinson, 1983: 241) gives the notion of directive as the utterance which is used by a speaker to get the hearer to do something. Similarly, Holmes says that directive is a linguistic utterance which is meant to ask someone to do something (1992: 239).

\section{Types of Directive Speech Acts}

Yule (1996: 54) classifies directive speech acts into four types:

1. Commanding 
Commanding is a speech act that is usually used by someone who has a power. Kauffman (2012: 132) states "commands are taken as ordering source, while the modal base is consisted by what the speaker and the hearer jointly take to be possible future courses or event." So that, command and ordering have similar context. Example: Now, read the chapter two!

The example tells us how someone gives the command to other person. The situation can be illustrated as the teacher commands his students to read the chapter of the book of the certain subject. The teacher uses the imperative sentence which begins with the infinitive verb and end by exclamation.

2. Ordering

Ordering is giving an order to somebody else to do thing. An order is usually used for public interest such as customer and seller. Kauffman (2012: 131) argues that orders have been singled out as the defaults usage of imperative. The sentence of orders is usually using direct utterance and the type of its sentence can be uttered in explicit or implicit utterance that the function is to give an order. For example: Give me a cup of coffee, Make it black!

The sentence tells us the speech event that is occurred in a certain place by a certain person. The sentence uses imperative sentence which function is orders. The event is illustrated as the speech event that happened in a café between costumers and a steward. The speaker as a customer has the right to give an order to the listener as a steward. Yet, social context that show the position of the addressers and addresses.

\section{Requesting}

Requesting is speech acts which human politely asking for things to others. Request is asking someone to do or not to do something or to express the need or desire for something (Rue, 2008:1). In addition, Searle (1969: 14) states that "the point of request is try to get the hearer to do something and no necessarily to commit or obligate him to do it." It means that requesting can be conducted by interrogative sentence, as the person does not force the other to do something but they politely want someone to do something without command directly. Example: Could you read this story for me?

The example tells us how someone asks the other person to read the letter for him using interrogative sentence. The situation can be illustrated as the request from the son to his mother to read the story before he sleeps. The son asks politely to his mother as his mother is older than him.

4. Suggesting

Suggestionis a speech that is used by someone to give an idea to somebody else's mind. Kauffman (2012: 153) states that in suggestion of speech there are no sincere without believing that is already true or is being made true by its very utterance. It means that a suggestion is a set of ideas and conclusion which is acquired by state of affair of speaker to solve the speaker's problem. A suggestion can be delivered as an advice from the speaker to the listener. Suggesting usually uses modal "should". Modal 'Should' and 'had better' are used for asserting suggestion, advice, opinion, hope, and desirability (Djuhari 2010: 67). Example: You should go to doctor. It will make you better.

The example tells us how someone gives the suggestion to the other person. The situation can be illustrated as someone who got toothache for three days, then he met his friends who suggested him to go to the dentist.

\section{Responds of Directive Speech Acts}

The respond here refers to the notion of an action, though and belief which are caused by illocutionary act. Austin called them as perlocutionary act whereby in the action resulted from uttering sentence (1955: 101). Related to the categories here, Leech (1983: 106) states that directive utterances are intended to produce some action by the hearer. It means that the responds of directive utterance appear in the form of action which is asked by the speaker.

\section{METHODOLOGY}

The research method chosen by the researcher to analyze the responds of directive speech acts by the characters in 
Jack the Giant Slyer (2013) movie is qualitative analysis method.

Qualitative research is important in humanity sciences where the aim is to discover the underlying motives of human behavior. Through such research, it can analyze the various factors which motivate people to behave in a particular manner or which make people like or dislike a particular thing (Kothari 2004: 3). The goal of qualitative research is to "better understand human behavior and experience...grasp the processes by which people construct meaning and to describe what those meaning are" (Bogdan and Biklen,1998: 38).

Qualitative research concerned with a quality of information, qualitative methods attempt to gain an understanding of the underlying reasons and motivations for actions and establish how people interpret their experiences and the world around them. Qualitative methods provide insights into the setting of a problem, generating ideas and/or hypotheses.

The data of this research is the directive speech act taken from Jack the Giant Slyer (2013) moviethat has been downloaded in www.youtube.com.

The data are taken from the movie "Jack the Giant Slyer (2013)". This movie is premiered on March 1, 2013 in USA. The genre of this movie is fantasy adventure so that, this movie is easy to analyzed.

\section{DISCUSSIONS}

Leech (1983) said that directive speech acts are intended to produce the action. Thus, the responds should be in the form of action. In fact, there are some utterances that are responded by verbal responds, actions and verbal responds, and even no responds. The following data are the sample of analysis of the responds from the characters in the movie.

\section{Action Responds}

Action respond is the responds showed by the characters that are expressed in directive speech act. Leech (1983: 106) states that directive utterances are intended to produce some action by the hearer. It means that the responds of directive utterance appear in form of action which is asked by the speaker.

\section{(1) Data 1}

Mother : I want you to have adventures. It'll make you a better queen.

Isabelle : How?

Mother : Because you'll get to see how the world works. And when you're queen, you'll have the power to make the world a better place. Now off to sleep! Sweet dreams, Isabelle.

(Isabelle directly closed her eyes when her mother commands her to sleep)

The dialogue above shows the utterances and the respond of the characters represented in the movie. The characters in that dialogue are Isabelle and her mother. Isabelle was asked to sleep when she had been read the story book by her mother and the respond of the command that given by her mother is that Isabelle directly closed her eyes when her mother left her in her bed room. She did not respond to her mother's command by the utterance but by the action. Leech (1983: 106) states that directive utterances are intended to produce some action by the hearer. It means that the responds of directive utterance appear in form of action which was asked by the speaker. The action showed by Isabelle in responding the command is in line with the theory from Leech above.

\section{(2) Data 9}

\section{Soldier: Stop that..... monk! Watch out! You there! Stop! Grab him! Take him down! Block the exit! Grab him now! Stay where you are! Don't move!}

The commanding directive utterances above are said by the soldier to the people around the castle. The soldier gave the command to all people in order to find the monks. When the monks are known, the soldier gram him and took him down as the soldier asked. And the monk stayed when he asked him to stay. The action showed by the soldiers who grabbed the monk, and the monk who stayed after when asked by the soldier is the action responds of commanding directive speech act. 
(3) Data 20

$\begin{array}{ll}\text { Elmont } & \text { : Crawe? It's her, yes? } \\ \text { Crawe } & \text { : Course it's her. She's } \\ \text { a smart girl. } & \text { : Isabelle? So she can } \\ \text { Elmont } & \text { : } \\ \text { find her way back. Keep up, or you'll be } \\ \text { left behind! } \\ \text { Soldiers }\end{array}$

The dialogue above happened between Elmont, Crawe, and the other soldiers. The soldiers were left behind Elmont and Crawe so that Elmont gave them command in order they kept walking together. When Elmont said "Keep up, or you'll be left behind!" the soldiers were directly running to catch Elmont and Crawe. The actions showed by the soldiers are a directive responds from the hearer to the speaker. Yule (1996:54) said that directive utterance is a speech acts by asking someone to do thing. In addition, Leech (1983: 106) stated that directive utterances are intended to produce some action by the hearer. It means that the responds of directive utterance appear in form of action which is asked by the speaker.

\section{(4) Data 21}

Bald : Something big pulled her out of there. She's in trouble.

Elmont : Bald...... go with Wicke and Roderick. Take the high ground! We'll continue on this way. Don't engage in anything unless you have to. Our mission is to findand return the princess. And we must assume that this is now hostile territory. And that every story your fathers... told you was true.Good luck.

(01:15:58)

Bald, Wicke, Roderick and Elmont were trying to save Isabelle. They knew that Isabelle was in big trouble. Elmont commanded Bald to go with Wick and Roderick. After he was commanded to go with them, Bald directly took his position which was close to Wick and Roderick then they went together with taking the high ground. The action showed by Bald was the directive responds from the directive utterance that had been given to him.

\section{Verbal Responds}

Verbal responds are the responds showed by the characters via utterances or spoken when they are given directive speech act by the other characters.

\section{(1) Data 12}

Isabelle : Then let me. Let me show you how responsible I can be. Let me get to know the people that I am meant to lead. Let me step outside without sending a dozen guards to rescue me.

Father: The day I lost your mother was the darkest day of my life. I do not intend to lose you too.

Isabelle: You'd allow me to find my own way. Mother said I should marry for love, but in my own time. Please, Father let me show you that I am capable.

Father : You belong in the safety of the palace. You will marry Roderick. There's nothing further to discuss.

Isabelle asked her father to let her shows how responsible she can be. She wants to get the trusty from her father. She wants to have an adventure but her father worried to let her as he do not want to lose her as he was losing her wife. Isabelle keeps asking her father to let her "Please, Father let me show you that I am capable", but her father answered that Isabelle belong in the safety of the palace. The verbal respond of the father to Isabelle is a verbal respond of requesting directive speech act that was said by her father.

\section{(2) Data 16}

King : What were you doing with my daughter's bracelet?

Jack: Hmm?

Soldiers: Down!

Jack: Hmm? No, I didn't steal it. I promise. She showed up at my house looking for shelter. I was trying to help her, Your Majesty, and then...

King : And then?

Jack: All this happened.

King: Wait a minute, I recognize you from the market. Your name is, uh, Jack. Let him up. And where is your house, Jack?

King : Elmont... Assemble a team! Men who can climb! 
Elmont : Yes, sire. I'd like to accompany them. With due respect, this mission is likely to be arduous.

The king asked Elmont to assemble the team who can climb to find Isabelle. Then Elmont responds the king's command by saying "Yes, sire. l'd like to accompany them". The utterances said by Elmont are verbal responds of commanding directive speech act said by the king.

\section{(3) Data 26}

Jack :Isabelle...you should imagine all the good things you could do.

Isabelle: That's what mymother used to say.

Isabelle is suggested by Jack to imagine all the good things as they want to jump. Then Isabelle responds Jack's suggestion by saying "That's what my mother used to say". The utterance said by Isabelle to Jack is the verbal or spoken respond of suggestion directive speech act.

\section{Action and Verbal Responds}

Action and verbal responds mean that the respond showed by the characters as the spoken or action responds. Example:

\section{(1) Data 1}

Father : Jack, you're still up?

Jack : Sorry, Father. The giants woke me.

Father : Jack, heh, it's a thunderstorm.

Jack : Mother used to say the giants made the thunder. Look!

Father : Where did you find that?

Jack : Along with her old things. Will you read the rest to me?

Father : All right.

The dialogue occurred between two characters. They are Jack and his father. Jack was very curious with the giant story. His imagination was controlled by giant in the story. When his father came to check him, he is still awake. He kept asking his father about the giant and asking to read the rest of the book using the utterance "will you read the rest to me?"
The action showed by Jack's father when he was asked to read the book by his son. He directly took the book and read it for his son. Leech (1983: 106) states that directive utterances are intended to produce some action by the hearer. It means that the responds of directive utterance appear in form of action which was asked by the speaker.

\section{(2) Data 4}

Jack : Leave that one!

Father: All right. Now get some sleep, son!We have to be out on the field before first light.

In the dialogue, Jack asked his father to leave his book before his father left his room. When Jack said "Leave that one!", his father did not only answer "Alright" but he responded with putting the book beside Jack. Then, before the father left the room, he asked Jack to sleep "Now get some sleep, son!" and Jack directly closed his eyes. The verbal or word and actions showed by characters can be indicated as the responds of directive speech act that is given to them.

\section{(3) Data 32}

Elmont: Close the drawbridge! It stays open till I give the command! Form into ranks! Up to the battlements, now!Ready the archers! Release the oil! Steady, men! Ready! Wait for it! Wait for it. Light it up! Raise... the drawbridge!

Jack: Elmont, no!

Elmont: Bring it up! Together! Keep running, boy! Come on, Jack!

Jack: Wait! Come on, Anser! Jack! Elmont: Move in! Draw! Fire!

$(00: 27: 04)$

The dialogue occurred between two characters. They are Jack and Elmont. The situation is when all the people were in the castle and they want to close the gate of the castle in order the giant could not get into the castle. Elmont asked the soldiers to close the gate "Close the drawbridge! It stays open till I give the command! Form into ranks! Up to the battlements, now! Ready the archers! Release the oil! Steady, men! Ready! Wait for it! Wait for it. Light it up! Raise... the drawbridge!. When the soldiers 
were commanded by Elmont they took their position to do what Elmont commands for.

When the gate is almost closed, Jack was still running outside. Jack screamed "Elmont, No!" then Elmont asked Jack to keep running faster "Bring it up! Together! Keep running, boy! Come on, Jack!. Hearing the commands from Elmont, Jack kept running faster. The utterance said and the actions showed by the characters are the directive responds of commanding directive speech acts that are given by Elmont as the commander.

\section{No Responds}

When someone asks to do something directly, they commonly do it. However, based on this analysis, there are some directives utterances which do not result the action or verbal responded. Example:

(1) Data 10

Uncle : I don't ask for much in return for all those years. I put food in your belly, clothes on your back, a roof over your head. So, what do I have to show for it? Beans?

Jack : I'll take them to the abbey tomorrow and tell the monks what happened.

Uncle : You believe that story?

Jack : I mean he was a monk.

Uncle : Because he wore a robe?

Funny haircut?

Jack : Yeah. No.

Uncle : Monks have no money.

They're monks! The man robbed you! Jack, you have got to grow up. You're 18 years old.

(Minute: 01:37:27)

Jack was reprimanded by his uncle as he is failed to sell the horse. Jack changed the horse with the beans from the monk. It made his uncle angry with him. Jack kept trying to make his uncle sure that he would take the beans to the abbey and told the monk what happened but his uncle did not trust the story at all. He told Jack "Jack, monks have no money. They're monks! The man robbed you! Jack, you have got to grow up. You're 18 years old". When Jack were suggested by his uncle, he did not say and did not do anything. So based on the reason, the researcher indicates it as no responds.

\section{(2) Data 11}

Uncle : Just like your father. Head in the clouds. Useless!

Jack : I can fix this. I promise.

Uncle : Too late for that. Nothing left to fix. Never thought it'd come to this. Your parents' things.Should fetch a few weeks' worth at the market. Take my legs half the night to get there with no horse.

Jack : You can't sell those.

Uncle : They aren't yours to sell. Horse was. Cart too. Jack, it was a simple task. Sell the horse, buy some thatch, fix the roof! You've got to take responsibility.

The uncle was angry with Jack as Jack changed his horse with the beans from the monk. Jack tried to fix that problem but his uncle told that it was too late to do it. His uncle told jack that his task was a simple task, "Jack, it was a simple task. Sell the horse, buy some thatch! Fix the roof! You've got to take responsibility". When Jack was suggested by his uncle, he did not do anything. He just listened to his uncle's words.

\section{(3) Data 13}

Roderick : Well? Did you get anything out of him?

Wick : No. He wouldn't spill the beans.

Roderick : I'm going to ask you just once: Where are they?

Monk : You should have left them where they were buried. They are born of dark magic.

The dialogue occurred between Roderick, Wick and the monk. Roderick asked Wick to take the beans from the monk but Wick could not do it. Then Roderick asked the monk by himself about those beans and the monk answered "You should have left them where they were buried. They are born of dark magic". And Roderick was only listening to his words as he was angry to the monks. 


\section{CONCLUSIONS}

Based on the research and the discussion, the result of the analysis about directive speech acts in the movie "Jack the Giant Slyer (2013)" movie shows that in asking the characters to do thing, some directive speech acts intended the hearer to do the action, for instance, when Isabelle's mother asked her daughter to sleep, Isabelle directly closed her eyes. It is what has been called as responds of the characters when they are given directive speech acts.

As Leech said that directive speech acts should be responded by actions yet based on the data analysis, the researcher found some directive speech acts that are not only responded by actions but also by the verbal responds, verbal with action respond, and even no responds. Verbal responds are the responds showed by the characters via utterances or spoken, action and verbal responds are the responds showed by the characters with not only by the action but the characters answered the directive speech act while doing action, and no responds mean that the characters do not answers or do anything when they are given directive speech act.

The most common type of directive speech acts that are responded by the action is commanding, and the least of it is suggesting. As whole, social factors and dimension of contexts support directives speech acts.

\section{REFERENCES}

Ad-darraji, Hadher Hussein Abood. 2012. Offering as Comissive and Directive Speech Acts. "International Journal of Scientific and Research Publication" Vol.2 Issue 3. 2012.

Austin, J.L. 1996. How to Do Things with Words (second edition). Massacushetts: Harvard University Press.

Bogdan, R. C., and Biklen, S. K.1998. Qualitative research in education: An introduction to theory and methods (3rd edision.). Needham Heights, MA: Allyn and Bacon.

Chaer, Abdul dan Agustina, Leonie. (2010). Sosiolinguistik Perkenalan Awal. Jakarta: Rineka Cipta.

Djuhari, Otong Setiawan. 2008. Functional English Grammar - Memahami dan Menerapkan Tata Bahasa Inggris Lewat Ekplorasi Model dan Latihan. Bandung: Yrama Widya.

Holmes, Janet. 1992. An Introduction to Sociolinguistics. London: Longman.

Kauffman, Magdalena. 2012. Interpreting Imperatives. London New York: Springer Dordrecht Heidelberg.

Khotari, C.R. 2004. Research Methodology: Research and Technique (Second Revised Edition). New Delhi: New Age International (P) Limited, Publisher.

Leech, Geoffrey N. 1983. Principles of Pragmatic. United States of America: Longman inc, New York.

Levinson, Stephen C. 1983. Persumtive Meaning- The Theory of Centralized Conversational Implicature. New York: The MIT Press.

Nastri, J., Peña, J., \& Hancock, J. T. (2006). The Construction of Away Messages: A Speech Acts Analysis . Journal of Computer-Mediated Communication.

Saeed, Jhon. I. 1997. Semantics. Oxford: Blackwell Publisher. 
Searle, Jhon R. 1969. Speech Actss: An Essay in the Philosophy of Language. Cambridge: Cambridge University Press.

Yule, George. 1996. Pragmatics. New York: Oxford University Press. 